\title{
Emerging breast cancer epidemic: evidence from Africa
}

\author{
Sally N Akarolo-Anthony', Temidayo O Ogundiran² and Clement A Adebamowo 1,3,4*
}

\section{Introduction}

Cancer is an increasingly important public health problem in developing countries, including Africa [1]. As public and professional awareness of the cancer problem has grown, so has interest in the pattern of disease presentation, its epidemiology and treatment outcome. To date, however, there has been limited research about breast cancer in Africa. In the absence of systematic population-based cancer registration, most information has come from small clinical and pathology case series and the bias inherent in these types of studies has influenced current understanding of the pattern and characteristics of breast cancer in Africa.

In this communication, we review the evidence for an emerging epidemic of breast cancer in Africa, its risk factors and likely future course. We conclude that, despite limited data, rising incidence of breast cancer is being driven by increasing life expectancy, improved control of infectious diseases, and changing lifestyle, diet, physical activity and obstetric practices. We also review current beliefs about hormone receptor subtypes of breast cancer in Africa and suggest that this is probably not systematically different from the pattern in other populations after adjusting for factors such as age and that the reported differences are related to poor tissue handling and laboratory processing practices.

\section{Global trends in cancer epidemiology}

From an estimated 12 million new cases and 7.6 million deaths in 2008, the incidence of cancer worldwide is expected to rise to 26.4 million with 17 million deaths by 2030. Most of these new cases of cancer are expected to occur in the developing world, particularly India and China [2]. Current data suggest that cancer kills more people than HIV/AIDS, tuberculosis and malaria combined, but this overall picture hides significant variations

*Correspondence: cadebamowo@som.umaryland.edu

${ }^{4}$ Office of Strategic Information, Research and Training, Institute of Human

Virology, 252 Herbert Macaulay Way, Abuja, FCT 90000, Nigeria

Full list of author information is available at the end of the article in incidence in different parts of the world. Whereas cancer incidence is certainly rising in all developing countries, the poor control and persistence of old infectious diseases and emergence of new ones in Africa means that infections remain the major source of morbidity and mortality in this part of the world compared to Asia and Latin America, where the impact of non-communicable diseases has now become more predominant.

\section{Demographic change and breast cancer in Africa}

In general, breast and other cancers are not rare in Africa. The probability that a woman who lives to age 65 in Kampala would develop a cancer is only $20 \%$ lower than that of her European contemporary [3]. What differs markedly is the probability that the African woman will live to be 65 years of age compared to women in developed countries. Even if incidence is held constant, the change in this probability as a result of increased life expectancy at birth is an important cause of the increasing prevalence of breast cancer in Africa [4]. A comparison of the rate of change of the breast cancer atrisk population of a typical African country, Nigeria, with that of a developed country, France (a clue to the choice of these two countries lies in their performance at the 2010 Football World Cup in South Africa) shows that whereas the size of the at-risk population remains largely stable in France, it is increasing steeply in Nigeria (Figure 1). In France the breast cancer at-risk population increased from approximately 19 million women in 1990 to approximately 21 million in 2010 and is projected to remain at approximately 21 million over the next 10 years. In Nigeria on the other hand, the number of women at risk of breast cancer increased steadily from approximately 24.5 million in 1990 to approximately 40 million in 2010 and is projected to rise to over 50 million by 2020 .

\section{Epidemiological risk factors of breast cancer}

Incidence is not likely to be constant, however, and the direction of its change is related to changes in the epidemiological risk factors for breast cancer [5]. The incidence of breast cancer starts to increase at about the 


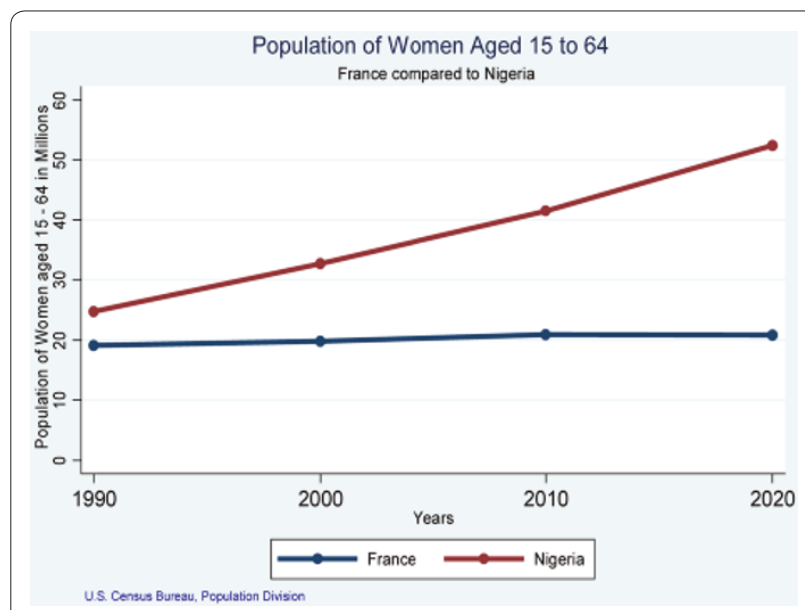

Figure 1. Comparison of the change in the relative proportion of breast cancer at-risk population in Nigeria and France from 1990 to 2020 .

age of 20 years and rises rapidly to about the age of 50 years, when the rate of increase reduces somewhat, and by 75 years of age the incidence starts to decline. This pattern has been observed in all populations with adequate data for analysis. The established risk factors for breast cancer include age, sex, age at onset of menarche, age at first full-term pregnancy, parity, breast feeding, age at onset of menopause, obesity and physical activity [5]. The direction of change in these risk factors in Africa is towards increasing incidence of breast cancer $[4,5]$. Age at onset of menarche is reducing because of improved nutrition and reduced physical activity. Increased demands for education and modern lifestyle choices are delaying the age at first full-term pregnancy and the fertility rate of African women, which is also contributing to reduced total lifetime breast feeding duration.

Analysis of African breast cancer cases and controls studied in Ibadan showed an association with height (adjusted odds ratio 1.05, 95\% confidence interval 1.01 to 1.08), a marker for nutrition in early life and with waisthip ratio (adjusted odds ratio 2.67, 95\% confidence interval 1.05 to 6.80$)[6,7]$.

A birth cohort analysis of the control participants recruited from 1998 to 2007 as part of a case-control study of the genetic risk factors of breast cancer in African women clearly demonstrates the effect of birth cohort on the epidemiological risk factors of breast cancer in African women. Comparing women born in the decades before 1940 with those born after 1960, the age at onset of menarche fell from 16.4 years to 15.3 years. Similarly, parity declined from 6 to 4 while the cumulative duration of breast feeding fell from an average of 120 months to 60 months [8]. These parameters still have some way to go before approximating western figures, suggesting that further changes will contribute to further increases in breast cancer incidence.

\section{Early onset breast cancer in African women}

Most African countries at this time have cone-shaped population pyramids, a reflection of high fertility rate coupled with high infant mortality rate; therefore, the majority of citizens are children and young adults with very little elderly populations. The median age is generally 20 years and below. In contrast, the population pyramids of developed countries approaches a cylinder in shape with more balanced distribution across all age groups and median age of about 40 years or higher (Figure 2). Because the African population has a low median age, breast cancer among young women comprises a higher proportion of the cases presenting in African clinics than among older women [3-5]. This demographydriven phenomenon has often been misinterpreted to suggest that breast cancer in African women tends to preferentially affect the young and that this reflects some intrinsic biological significance, but this is not so [3]. The misunderstanding derives from inappropriate comparison of the mean age at clinical presentation obtainable from clinical and pathology case series with age incidence data from populations with functional cancer registries and interpreted to suggest significant differences in age incidence of breast cancer comparing African women with women in developed countries.

Breast cancer among young women in any population tends to be clinically and pathologically aggressive, with rapid progression and a higher mortality rate compared to older women [9]. Because the African population is predominantly young and African breast cancer patients tend to be young, the pattern of breast cancer that presents to practitioners in Africa is mostly aggressive in clinical course with a high fatality rate. This is not an intrinsic African pattern of breast cancer, rather another manifestation of the demographic structure of the population.

\section{Molecular subtypes of breast cancer in Africa}

Another area of controversy in breast cancer in Africa is the characterization of the hormone receptor subtypes in the patient population. Several studies have suggested that African breast cancers are predominantly hormone receptor poor [10]. Pathologists and researchers working in low resource countries have encountered problems related to poor preparation and fixation of tissue samples, which has often led to inability to apply advanced immunohistochemical and molecular biology techniques [11]. These problems include poorly quality specimens from large and necrotic tumors, prolonged delay before fixation, questionable quality of fixative materials, prolonged stay in fixative (often for several weeks), poor 


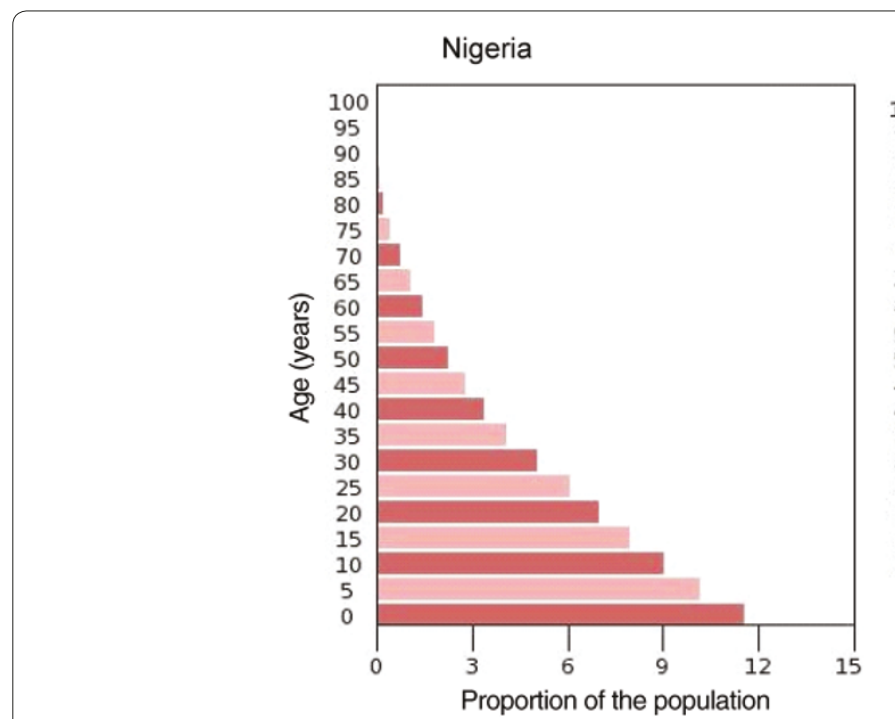

France

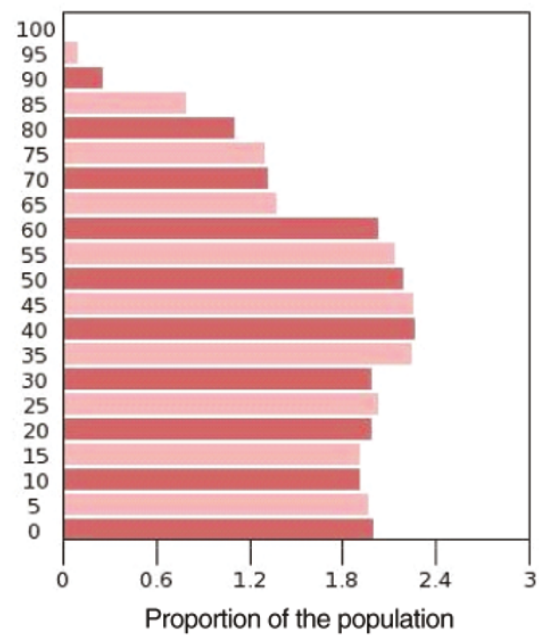

Figure 2. Comparison of the population pyramids of Nigeria and France in 2010.

laboratory techniques and quality assurance/quality control practices [11].

More systematic studies of breast cancer in Africa have not confirmed the suggestion that African breast tumors are predominantly receptor poor $[11,12]$. Given that similar claims have been made of breast cancer subtypes in other parts of the world and these have also been found to be untrue after careful studies and the wide variation in genetic and environmental characteristics of the different low resource environments where these observations had been made, poor tissue preparation rather than intrinsic biological characteristics is the likely reason for the results seen in some studies [11,13]. Compounding the problem of immunohistochemistry of breast tumors is the lack of methodological standardization even in developed countries, resulting in up to $20 \%$ variation in false positives and negatives and suboptimal utilization of the information currently generated by receptor assays [14].

\section{Significance of these controversies}

Despite improved understanding of the epidemiology of breast cancer and the impact of the current African demographic pattern on the age distribution, breast cancer affects many young and middle-aged African women at the most active phase of their social and economic life, resulting in significant economic, social, physical and psychological harm [9]. Research and implementation of methods of effective early detection, effective but low-cost, low-tech treatment of early onset breast cancer, and management of the social, economic and psychological sequelae of the disease are urgently required $[15,16]$. African breast cancer patients must be offered hormonal therapy where the hormone receptor status is unknown because of lack of immunohistochemical services. These are relatively inexpensive with tolerable toxicity profiles. Development of managed 'hub and spoke' regional pathology laboratory model systems that support several hospitals will improve the quality of pathology services and reduce cost. Training of clinicians and laboratory technicians to ensure proper tissue sampling and fixation is critical and of the foremost importance [11]. Much work remains to be done in order to better understand breast cancer in African women.

\section{Competing interests}

The authors declare that they have no competing interests.

\section{Acknowledgements}

This article has been published as part of Breast Cancer Research Volume 12 Supplement 4, 2010: Controversies in Breast Cancer 2010. The full contents of the supplement are available online at http://breast-cancer-research.com/ supplements/12/S4

\section{Author details}

'Department of Nutrition, Harvard School of Public Health, Boston, MA 02115 , USA. 2Division of Oncology, Department of Surgery, University of Ibadan, University College Hospital, Ibadan, Nigeria. ${ }^{3}$ Greenebaum Cancer Center, School of Medicine; Department of Epidemiology and Public Health, and Institute of Human Virology, University of Maryland, Baltimore, MD 21201, USA. ${ }^{4}$ Office of Strategic Information, Research and Training, Institute of Human Virology, 252 Herbert Macaulay Way, Abuja, FCT 90000, Nigeria.

\section{Published: 20 December 2010}

\section{References}

1. Farmer P, Frenk J, Knaul FM, Shulman LN, Alleyne G, Armstrong L, Atun R, Blayney D, Chen L, Feachem R, Gospodarowicz M, Gralow J, Gupta S, Langer A, Lob-Levyt J, Neal C, Mbewu A, Mired D, Piot P, Reddy KS, Sachs JD, Sarhan $M$, Seffrin JR: Expansion of cancer care and control in countries of low and middle income: a call to action. Lancet 2010, 376:1186-1193.

2. World Health Organization: Preventing chronic diseases: a vital investment: WHO global report. Geneva: World Health Organization; 2005. 
3. Parkin DM, Ferlay J, Hamdi-Cherif M, Sitas F, Thomas JO, Wabinga H, Whelan SL: Cancer in Africa: Epidemiology and Prevention. Lyon: IARC; 2003.

4. Adebamowo CA, Adekunle OO: Case-controlled study of the epidemiological risk factors for breast cancer in Nigeria. Br J Surg 1999, 86:665-668.

5. Adebamowo CA, Ajayi OO: Breast cancer in Nigeria. West Afr J Med 2000, 19:179-191.

6. Adebamowo CA, Ogundiran TO, Adenipekun AA, Oyesegun RA, Campbell $\mathrm{OB}$, Akang EU, Rotimi CN, Olopade Ol: Obesity and height in urban Nigerian women with breast cancer. Ann Epidemiol 2003, 13:455-461.

7. Adebamowo CA, Ogundiran TO, Adenipekun AA, Oyesegun RA, Campbell $\mathrm{OB}$, Akang EE, Rotimi CN, Olopade Ol: Waist-hip ratio and breast cancer risk in urbanized Nigerian women. Breast Cancer Res 2003, 5:R18-24.

8. Ogundiran TO, Huo D, Adenipekun A, Campbell O, Oyesegun R, Akang E, Adebamowo C, Olopade Ol: Case-control study of body size and breast cancer risk in Nigerian women. Am J Epidemiol 2010, 172:682-690.

9. Anders CK, Johnson R, Litton J, Phillips M, Bleyer A: Breast cancer before age 40 years. Semin Oncol 2009, 36:237-249.

10. Bird PA, Hill AG, Houssami N: Poor hormone receptor expression in East African breast cancer: evidence of a biologically different disease? Ann Surg Oncol 2008, 15:1983-1988.

11. Adebamowo CA, Famooto A, Ogundiran TO, Aniagwu T, Nkwodimmah C, Akang EE: Immunohistochemical and molecular subtypes of breast cancer in Nigeria. Breast Cancer Res Treat 2008, 110:183-188.

12. Togo A, Traore A, Traore C, Dembele BT, Kante L, Diakite I, Maiga A, Traore SO, Coulibaly AC, Diallo G: Cancer du sein dans deux centres hospitaliers de
Bamako (Mali): aspects diagnostiques et thérapeutiques. J Africain Cancer 2010, 2:88-91.

13. Love RR, Duc NB, Allred DC, Binh NC, Dinh NV, Kha NN, Thuan TV, Mohsin SK, Roanh le D, Khang HX, Tran TL, Quy TT, Thuy NV, Thé PN, Cau TT, Tung ND, Huong DT, Quang le M, Hien NN, Thuong L, Shen TZ, Xin Y, Zhang Q, Havighurst TC, Yang YF, Hillner BE, DeMets DL: Oophorectomy and tamoxifen adjuvant therapy in premenopausal Vietnamese and Chinese women with operable breast cancer. J Clin Oncol 2002, 20:2559-2566.

14. Hammond ME, Hayes DF, Dowsett M, Allred DC, Hagerty KL, Badve S, Fitzgibbons PL, Francis G, Goldstein NS, Hayes M, Hicks DG, Lester S, Love R, Mangu PB, McShane L, Miller K, Osborne CK, Paik S, Perlmutter J, Rhodes A, Sasano H, Schwartz IN, Sweep FC, Taube S, Torlakovic EE, Valenstein P, Viale G, Visscher D, Wheeler T, Williams RB, et al:: American Society of Clinical Oncology/College Of American Pathologists guideline recommendations for immunohistochemical testing of estrogen and progesterone receptors in breast cancer. J Clin Oncol 2010, 28:2784-2795.

15. Adebamowo CA: Opportunities for collaborative research and training on cancer in Africa. Afr J Med Med Sci 2009, 38 Suppl 2:3.

16. Adebamowo CA, Akarolo-Anthony S: Cancer in Africa: opportunities for collaborative research and training. Afr J Med Med Sci 2009, 38 Suppl 2:5-13.

doi:10.1186/bcr2737

Cite this article as: Akarolo-Anthony SN, et al:: Emerging breast cancer epidemic: evidence from Africa. Breast Cancer Research 2010, 12(Suppl 4):S8. 